\title{
Rhein Inhibits TNF- $\alpha$-Induced Human Aortic Smooth Muscle Cell Proliferation via Mitochondrial-Dependent Apoptosis
}

\author{
Sook-Kyoung Heo Hyun-Jeong Yun Won-Hwan Park Sun-Dong Park \\ Cardiovascular Medical Research Center and Department of Prescriptionology, University of Dongguk, \\ Gyeongju City, Republic of Korea
}

\section{Key Words}

Rhein - Apoptosis - Caspase activation - Mitochondrial pathway $\cdot$ Anti-atherosclerosis

\begin{abstract}
Background: Vascular smooth-muscle cell proliferation plays an important role in atherosclerosis and restenosis. Rhein is an active component extracted from rhubarb. In this study, rhein was found to exert potent inhibitory effects against tumor necrosis factor (TNF)- $\alpha$-induced human aortic smooth-muscle cells (HASMCs) proliferation. Method: These effects were associated with induced apoptosis, including the induction of Annexin V-positive cells, the cleavage of poly(ADP-ribose)polymerase (PARP), and caspases 3, 8 and 9. Results: Inhibitors of caspases 3, 8 and 9 were efficiently blocked by rhein-induced apoptosis in TNF- $\alpha$-treated HASMCs. In addition, treatment with rhein resulted in the release of cytochrome $c$ into the cytosol, a loss of mitochondrial membrane potential $\left(\Delta \psi_{\mathrm{m}}\right)$, a decrease in $\mathrm{Bcl}-2$ and $\mathrm{BCl}-\mathrm{xL}$ and an increase in Bax and Bak expression. However, rhein-mediated apoptosis was blocked by a mitochondrial membrane depolarization inhibitor. These findings indicate that rhein-induced apoptosis occurred via a mitochondrial pathway. Furthermore, the inhibition of mitochondrial membrane depolarization was efficiently blocked by rhein-in-
\end{abstract}

duced caspase-9 activity, which indicates that the rhein-induced caspase activation signal was downstream of the mitochondrial pathway. Taken together, the results of this study show that rhein inhibits TNF- $\alpha$-induced HASMC proliferation via mitochondria-dependent apoptosis and that rhein has the potential to act as an anti-atherosclerosis agent.

Copyright $\odot 2009$ S. Karger AG, Basel

\section{Introduction}

The proliferation, differentiation or change in molecular regulation of vascular smooth muscle cells (VSMCs) induces diseases including atherosclerosis and restenosis $[1,2]$. Following vascular injury, a loss of differentiated phenotype and a shift to a synthetic phenotype such as proliferation occurs [2, 3]. Vascular lesions form during several pathological processes, including the accumulation of inflammatory cells and the production of inflammatory cytokines such as tumor necrosis factor (TNF)- $\alpha$, interleukin (IL)-8 and monocyte chemoattractant protein-1 (MCP-1) and so on [3]. Especially, TNF- $\alpha$ is secreted by VSMCs in the neointima after a balloon injury as well as by macrophages in atherosclerotic lesions $[3,4]$. Previous studies have shown that TNF- $\alpha$ induces an in-

\section{KARGER}

Fax +4161306 1234 E-Mail karger@karger.ch www.karger.com
(C) 2009 S. Karger AG, Basel

$1018-1172 / 09 / 0464-0375 \$ 26.00 / 0$

Accessible online at:

www.karger.com/jvr
Prof. Dr. Sun-Dong Park

Cardiovascular Medical Research Center and Department of Prescriptionology

College of Oriental Medicine, Dongguk University

Sukjang-Dong 707, Gyeongju City, Gyeongbuk 780-714 (Republic of Korea)

Tel. +82 54770 2371, Fax +82 54770 2654, E-Mail hsk927@yahoo.com 
crease in DNA synthesis as well as the proliferation of VSMCs [5-9].

Apoptosis is one method of controlling immune responses. Apoptosis is characterized by a number of welldefined features, such as cellular morphological changes, chromatin condensation, oligonucleosomal DNA cleavage, membrane blebbing and activation of a family of cysteine proteases known as caspases [10]. Caspase activation is triggered in the mitochondrial-initiated pathway by the formation of a multimeric Apaf-1/cytochrome $c$ complex that recruits and activates procaspase-9. Activated caspase- 9 will then cleave and activate downstream caspases such as 3, 6, 7, 8 and $10[11,12]$. Caspase-3, in turn, cleaves many substrates that respond to DNAstrand breaks, including poly(ADP-ribose)polymerase (PARP), and eventually leads to apoptosis [13]. Also, protein $\mathrm{Bcl}-2$ families affect the integrity of mitochondria and caspase activation [14]. The Bcl-2 family consists of the pro-apoptotic proteins, Bax and Bak, as well as the anti-apoptotic proteins, Bcl-2 and Bcl-xL. Bax translocation directly induces the release of cytochrome $c$ from mitochondria in apoptotic cells and triggers disruption of the mitochondrial membrane potential [15-17]. In contrast, Bcl-2 and Bcl-xL bind to mitochondria and inhibit the release of cytochrome $c[14,18]$.

Rhein (4, 5-Dihydroxyanthraquinone-2-carboxylic acid), a constituent enriched in the rhizome of rhubarb (Rheum palmatum L. or Rheum tanguticum Maxim, daehwang in Korean), is a traditional Chinese herb that is used as a laxative and stomach drug [19]. It is well known that rhein has anticancer activity in various cells, including human glioma cells [20], tumor cells in the rat liver [21], Ehrlich ascites tumor cells [22], human colonic adenocarcinoma [23], the mouse epidermal cell line JB6 [19], human promyelocytic leukemia HL-60 cells [24] and human cervical cancer Ca Ski cells [25]. However, little is known about the anti-atherogenic effects of rhein. Therefore, in this study, we evaluated rhein to determine if it inhibits TNF- $\alpha$-induced human aortic smooth-muscle cell (HASMC) proliferation via a mitochondria-dependent apoptotic pathway.

\section{Materials and Methods}

\section{Reagents}

Rhein was purchased from Sigma Chemical Co. (St. Louis, Mo., USA). Recombinant human TNF- $\alpha$ was purchased from R\&D Systems (Minneapolis, Minn., USA) and diluted in $0.1 \%$ bovine serum albumin (BSA)-phosphate-buffered saline (PBS) buffer. A CellTiter $96^{\circledR}$ Aqueous One Solution cell proliferation assay
(MTS) kit was purchased from Promega (Madison, Wisc., USA). Aprotinin, leupeptin, DMSO, dithiothreitol (DTT), Ac-DEVD$\mathrm{CHO}, \mathrm{DiOC}_{6}(3)$ dye, bongkrekic acid (BA) and phenylmethylsulfonyl fluoride (PMSF) were purchased from Sigma Chemical Co. Z-IETD-FMK and Z-LEHD-FMK were purchased from R\&D Systems. Anti-Bcl-xL, Bax, cleaved PARP, $\beta$-actin monoclonal antibody $(\mathrm{mAb})$ and cleaved caspase-3, 8, 9 were purchased from Cell Signaling Technology (Beverly, Mass., USA). Anti-Bak mAb, anti-rabbit IgG horseradish peroxidase (HRP) and anti-mouse IgG HRP were purchased from Santa Cruz Biotechnology (Santa Cruz, Calif., USA). Anti-cytochrome $c$ and Bcl-2 mAb were purchased from BD Pharmingen (San Jose, Calif., USA). The caspase9 assay system (colorimetric; Ac-LEHD-pNA) was purchased from Biomol (Plymouth Meeting, Pa., USA). A BrdU-(5'Bromo2-deoxyuridine) ELISA assay kit was purchased from Roche Diagnostics (Mannheim, Germany). A vibrant apoptosis assay kit was purchased from Invitrogen (Carlsbad, Calif., USA).

\section{Cell Cultures}

HASMCs, smooth muscle cell medium (SMCM), and SMC growth supplement were purchased from ScienCell (Carlsbad, Calif., USA). According to the manufacturer's instructions, SMCM is a complete medium designed for optimal growth of normal human SMCs in vitro. It contains essential and nonessential amino acids, vitamins, organic and inorganic compounds, hormones, growth factors, trace minerals and a low concentration of fetal bovine serum (2\%). Thus, HASMCs were grown in SMCM including growth supplement and a low concentration of fetal bovine serum $(2 \%)$ at $37^{\circ} \mathrm{C}$ in a humidified $95 \%$ air $/ 5 \% \mathrm{CO}_{2}$ atmosphere. For all experiments, HASMCs were grown to $80-90 \%$ confluence and then made quiescent by starvation for at least $24 \mathrm{~h}$.

\section{Cell Proliferation Assays}

Cell proliferation was measured with a CellTiter 96 colorimetric assay using an MTS tetrazolium compound according to the manufacturer's instructions. Briefly, cells were seeded in 96-well culture plates in SMCM, and then treated as described above for $24 \mathrm{~h}$. Assays were then performed by adding [3-(4,5-dimethylthiazol-2-yl)-5-(3-carbo-xymethoxyphenyl)-2-(4-ulfenyl)-2Htetrazoli-um] (MTS) directly to the culture wells, followed by incubation for $4 \mathrm{~h}$. In addition, cell proliferation was measured by a BrdU-(5'Bromo-2-deoxyuridine) ELISA assay (cell proliferation ELISA BrdU), which was performed according to the instructions of the manufacturer. Briefly, cells were seeded in 96-well culture plates in SMCM, and were then treated as described above for $24 \mathrm{~h}$. Assays were then performed by adding BrdU (10 $\mu \mathrm{M}, 2 \mathrm{~h})$. For the BrdU technique, after cell fixation, DNA denaturation, and blocking, the cells were incubated with an anti-BrdU monoclonal antibody coupled to peroxidase and 3,3',5,5'-tetramethylbenzidine. The absorbance of both samples at $490 \mathrm{~nm}$ was then recorded using an enzyme-linked immunosorbent assay reader, Opsys MR (Dynex Technologies, Chantilly, Va., USA). The results were expressed as percentage changes from basal conditions using 3 to 5 culture wells for each experimental condition.

\section{Analysis of Mitochondrial Membrane Potential}

The mitochondrial membrane potential $\left(\Delta \psi_{\mathrm{m}}\right)$ was assessed based on the retention of $\mathrm{DiOC}_{6}(3)$. Cationic lipophilic fluorochrome $\mathrm{DiOC}_{6}(3)$ is a cell-permeable marker that specifically ac- 
cumulates in the mitochondria depending on $\Delta \psi_{\mathrm{m}}$ [24]. HASMCs $\left(3 \times 10^{5} / \mathrm{ml}\right)$ were treated with various concentrations of rhein for $24 \mathrm{~h}$. The cells were then washed once in $0.2 \%$ BSA-PBS, after which they were incubated with $10 \mu \mathrm{M} \mathrm{DiOC}_{6}(3)$ for $30 \mathrm{~min}$ at $37^{\circ} \mathrm{C}$. Mitochondrial depolarization is indicated by a decrease in the $\mathrm{DiOC}_{6}(3)$ fluorescence intensity. In addition, in some experiments, $10 \mu \mathrm{M}$ of Ac-DEVD-CHO, Z-IETD-FMK and Z-LEHDFMK were added to HASMCs for $30 \mathrm{~min}$ prior to rhein and/or TNF- $\alpha$ treatment. After $24 \mathrm{~h}$, the cells were stained with $10 \mu \mathrm{M}$ $\mathrm{DiOC}_{6}(3)$ and then subjected to FACS analysis. As many as $1 \times$ $10^{4}$ cells were analyzed at FL1 using a Becton Dickinson FACSCalibur flow cytometer with the detection wavelength between 515 and $550 \mathrm{~nm}$ after excitation at $488 \mathrm{~nm}$, and Cell-Quest Pro software (BD Biosciences, San Jose, Calif., USA).

\section{Determination of Apoptosis by Flow Cytometry}

To detect externalized phosphatidylserine (PS) as an early indication of apoptosis, HASMCs $\left(3 \times 10^{5} / \mathrm{ml}\right)$ were incubated with various concentrations of rhein for $24 \mathrm{~h}$ at $37^{\circ} \mathrm{C}$. The cells were then harvested, washed twice with FACS buffer $(0.2 \%$ BSAPBS), stained with Annexin V-FITC and propidium iodide (PI) according to the protocol of the manufacturer, and then analyzed with a Becton Dickinson FACSCalibur flow cytometer and CellQuest Pro software. BA $(50 \mu \mathrm{M})$ was added to the HASMCs for $2 \mathrm{~h}$ before rhein and/or TNF- $\alpha$ treatment in order to inhibit disruption of the mitochondrial membrane potential (MMP). After $24 \mathrm{~h}$, the cells were stained with annexin V-FITC and PI for FACS analysis [26]. In some experiments, $10 \mu \mathrm{M}$ Ac-DEVD-CHO, ZIETD-FMK and Z-LEHD-FMK were added to HASMCs for 30 min prior to rhein and/or TNF- $\alpha$ treatment. After $24 \mathrm{~h}$, the cells were stained with Annexin V-FITC and subjected to FACS analysis.

\section{Preparation of Cytosolic Extractions for Cytochrome c}

Analysis

The cells were washed with ice-cold PBS, resuspended in cold lysis buffer (250 mM sucrose, $20 \mathrm{mM}$ HEPES, $10 \mathrm{mM} \mathrm{KCl}, 1.5 \mathrm{mM}$ $\mathrm{MgCl}_{2}, 1 \mathrm{~mm}$ EGTA, 1 mM EDTA, 1 mM DTT, 0.1 mM PMSF, 10 $\mu \mathrm{g} / \mathrm{ml}$ leupeptin, and $10 \mu \mathrm{g} / \mathrm{ml}$ aprotinin) and then incubated on ice for $30 \mathrm{~min}$. Next, the cells were homogenized with 15 strokes using a dounce homogenizer, after which they were centrifuged at $1,200 \mathrm{~g}$ for $15 \mathrm{~min}$ at $4^{\circ} \mathrm{C}$. The supernatants were then transferred to another tube and centrifuged at $100,000 \mathrm{~g}$ for $60 \mathrm{~min}$ at $4{ }^{\circ} \mathrm{C}$, after which they were analyzed by $12.5 \%$ sodium dodecyl sulfate-polyacrylamide gel electrophoresis (SDS-PAGE). The release of cytochrome $c$ was analyzed by immunoblotting using an anti-cytochrome $c \mathrm{mAb}$. In some experiments, BA $(50 \mu \mathrm{M})$ was added to the HASMCs for $2 \mathrm{~h}$ prior rhein and/or TNF- $\alpha$ treatment. After $24 \mathrm{~h}$, the cells were washed with ice-cold PBS and then resuspended in a cold lysis buffer for analysis by immunoblotting using an anti-cytochrome $c \mathrm{mAb}$.

\section{Preparation of Total Cell Extracts and Western Blotting}

After HASMCs were cultured with a variety of concentrations of rhein and/or $10 \mathrm{ng} / \mathrm{ml} \mathrm{TNF}-\alpha$ for $24 \mathrm{~h}$, they were washed 3 times with ice-cold PBS. The cells were then lysed in RIPA buffer (50 mM Tris- $\mathrm{HCl} \mathrm{pH} \mathrm{7.5,} 150 \mathrm{~mm} \mathrm{NaCl}, 10 \mathrm{~mm} \mathrm{NaF}, 1 \mathrm{~mm}$ $\mathrm{Na}_{3} \mathrm{VO}_{4}, 2 \mathrm{~mm}$ EDTA, $1 \% \mathrm{NP}-40$, and various protease inhibitors). Next, the cells were centrifuged at $12,000 \mathrm{~g}$ for $15 \mathrm{~min}$ at $4^{\circ} \mathrm{C}$, after which the supernatants were collected and referred to as the cell extract. The protein concentrations were then measured using Bradford protein dye reagent (Bio-Rad). Next, the total cell lysates from the HASMCs were separated by approximately $10-12.5 \%$ SDS-PAGE, after which the proteins were electrophoretically transferred onto nitrocellulose membranes. The membranes were then blocked with $5 \%$ non-fat dried milk in Trisbuffered saline, and subsequently probed with primary antibodies, anti-cleaved PARP, anti-Bcl-xL, anti-Bax and anti-Bcl-2 in Tris-buffered saline containing 3\% non-fat dried milk. Antibodyantigen complexes were then detected using goat anti-mouse IgGor goat anti-rabbit IgG-HRP-conjugated antibodies and an enhanced chemiluminescence detection kit.

Intracellular Staining for Bak Expression

HASMCs were incubated with various concentrations of rhein and/or $10 \mathrm{ng} / \mathrm{ml} \mathrm{TNF}-\alpha$ for $24 \mathrm{~h}$ at $37^{\circ} \mathrm{C}$. The cells were then harvested and washed twice with FACS buffer (0.2\% BSA-PBS). Next, cells were fixed with $4 \%$ paraformaldehyde in PBS, after which they were permeabilized with $0.1 \%$ Triton X-100 in PBS. The cells were then stained with anti-Bak $\mathrm{mAb}$ or isotype control $\mathrm{mAb}$ at $4^{\circ} \mathrm{C}$ for $30 \mathrm{~min}$, after which they were analyzed with a Becton Dickinson FACSCalibur flow cytometer and Cell-Quest Pro software. The percentage of positive cells was recorded for each sample. In some experiments BA $(50 \mu \mathrm{M})$ was added to HASMCs for $2 \mathrm{~h}$ prior to rhein and/or TNF- $\alpha$ treatment in order to inhibit disruption of the mitochondrial membrane potential.

\section{Measurement of Caspase-9 Activity}

Caspase activity was measured as described previously [27]. To accomplish this, the caspase- 9 activity was determined by measuring the absorbance at $405 \mathrm{~nm}$ after cleavage of the Ac-LEHDpNA substrate using the caspase- 9 assay system and a colorimetric kit, respectively. Briefly, HASMCs were adjusted to $10^{6}$ cells/ $\mathrm{ml}$, and various concentrations of rhein $(0,0.1,1,10 \mathrm{ng} / \mathrm{ml}), 10$ $\mathrm{ng} / \mathrm{ml} \mathrm{TNF}-\alpha$, or anti-caspase- $9 \mathrm{mAb}(5 \mu \mathrm{M})$ were then added according to the experimental design (positive controls). The mixtures were then incubated for $24 \mathrm{~h}$ at $37^{\circ} \mathrm{C}$, after which the cells were harvested by centrifugation at 2,000 rpm for $5 \mathrm{~min}$ at $4^{\circ} \mathrm{C}$, washed twice with ice-cold PBS, and then resuspended in cell lysis buffer. The cells were then lysed by repeated freezing and thawing, followed by incubation on ice for $15 \mathrm{~min}$. Next, the cell lysates were centrifuged at $16,000 \mathrm{~g}$ for $15 \mathrm{~min}$ at $4^{\circ} \mathrm{C}$, after which the supernatant fraction (cell extract) was collected. The caspase activities of the cell extracts were then measured in a total volume of $100 \mu \mathrm{l}$ in 96-well plates that contained at least $1 \times 10^{6}$ cells/assay. Triplicate wells were prepared, with each set containing a blank, a negative control, induced extracts and inhibited extracts, according to the instructions of the manufacturer. Cell extracts were used as an enzyme source. Each substrate $(10 \mu \mathrm{l})$ was added to all wells and the plate was then covered with Parafilm laboratory film and incubated at $37^{\circ} \mathrm{C}$ for $4 \mathrm{~h}$. The absorbance was then read in the wells at $405 \mathrm{~nm}$ using an ELISA reader (Opsys). The enzyme activity was then calculated from a standard curve prepared using pNA standard. The relative levels of pNA were normalized against the protein concentration of each extract. The specific activity of caspase- 9 was then calculated according to the number of micrograms of protein in each $100 \mu \mathrm{l}$ sample volume, which was determined by the Bradford method using a BSA standard curve. 


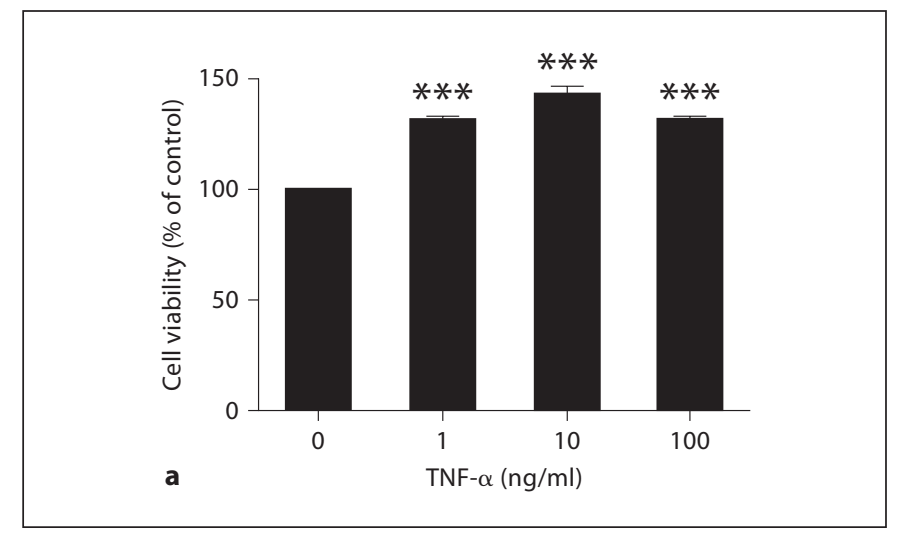

Fig. 1. Effect of HASMC proliferation induced by TNF- $\alpha$ and rhein. Arrested HASMCs were stimulated with $0.1,1$, or $10 \mu \mathrm{M}$ rhein for $30 \mathrm{~min}$ prior to treatment without (a) or with (b) $10 \mathrm{ng} / \mathrm{ml}$ TNF- $\alpha$ for $24 \mathrm{~h}$. The control group was not treated with TNF- $\alpha$ or rhein. HASMC proliferation was evaluated by a CellTiter 96 cell proliferation assay (upper panel) and by a BrdU-(5'Bromo-2deoxyuridine) ELISA assay (lower panel). Data shown are representative of at least 3 independent experiments. Data represent the means \pm SEM. ${ }^{* * *} \mathrm{p}<0.001$ vs. control $(0 \mathrm{ng} / \mathrm{ml} \mathrm{TNF}-\alpha$; $\mathbf{a})$ and TNF- $\alpha$ alone group (b).

\section{Statistics}

The data presented represent the means \pm SEM of at least three independent experiments. All values were evaluated by oneway ANOVA followed by Duncan's multiple range tests using the GraphPad Prism 4.0 software. Differences were considered significant at $\mathrm{p}<0.05$.

\section{Results}

\section{Rhein Inhibits the Proliferation of HASMCs}

We investigated the proliferation of HASMCs in response to treatment with $0,1,10$ and $100 \mathrm{ng} / \mathrm{ml}$ of TNF- $\alpha$. The results of a CellTiter 96 cell proliferation assay revealed that TNF- $\alpha$-stimulated the proliferation of HASMCs, with $10 \mathrm{ng} / \mathrm{ml}$ of TNF- $\alpha$ producing the maximum proliferation (fig. 1a). However, rhein significantly inhibited the TNF- $\alpha$-induced proliferation in a dose-dependent manner, with only 33,42 and $58 \%$ of the proliferation induced by treatment with TNF- $\alpha$ alone being observed in cells that were treated with TNF- $\alpha$ and rhein at final concentrations of $0.1,1$ and $10 \mu \mathrm{M}$, respectively (fig. 1b, upper panel). In addition, the effect of rhein on TNF- $\alpha$-induced proliferation was confirmed by a BrdU-

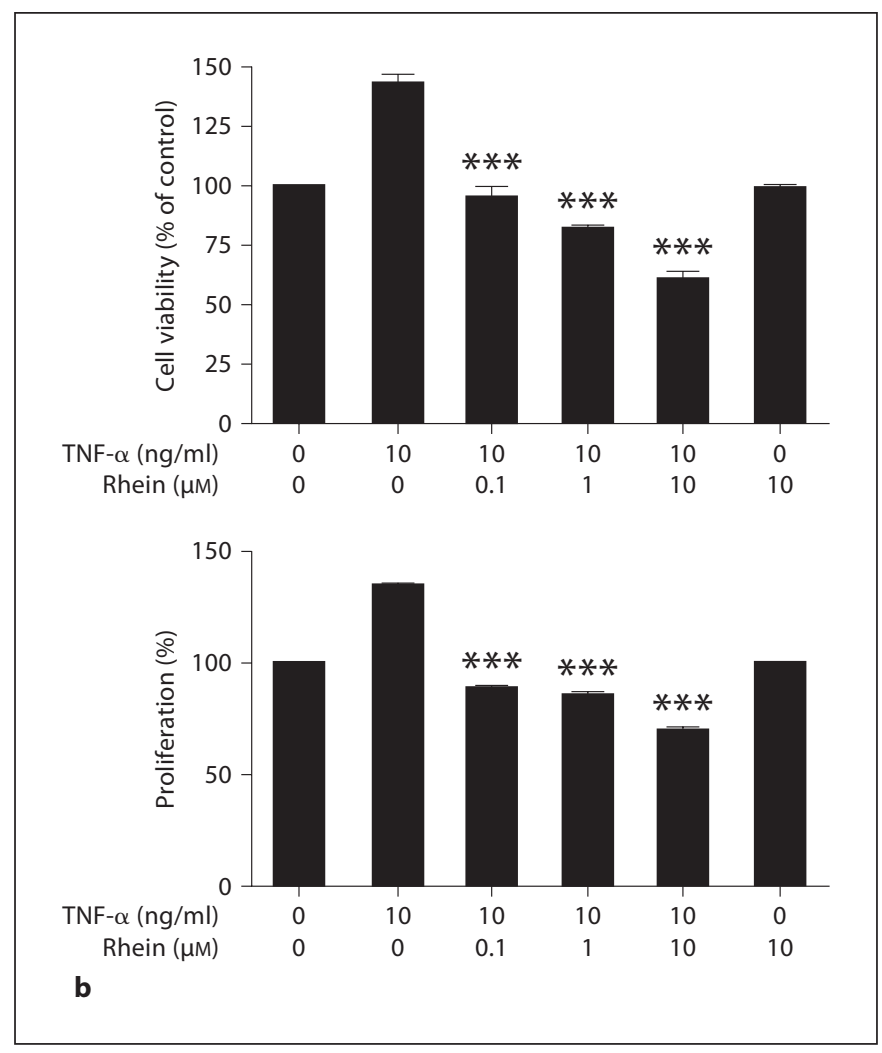

(5'Bromo-2-deoxyuridine) ELISA assay. Treatment with $0.1,1$ and $10 \mu \mathrm{M}$ rhein significantly and dose-dependently decreased the proliferation of HASMCs to 34,36 and $48 \%$ of that of cells that were treated with TNF- $\alpha$ alone, respectively (fig. $1 \mathrm{~b}$, lower panel). In addition, treatment with rhein alone $(10 \mu \mathrm{M})$ had no effect on the proliferation or cytotoxicity of HASMCs (fig. 1b).

\section{Rhein Induces Apoptosis in HASMCs Dependent on Caspase Activation}

Cells undergoing apoptosis showed characteristic changes such as nuclear condensation, DNA fragmentation and translocation of PS to the outer leaflets of the plasma membrane $[13,26]$. Apoptosis was measured by annexin $\mathrm{V}$ staining of PS following rhein treatment. HASMCs were incubated with TNF- $\alpha(10 \mathrm{ng} / \mathrm{ml})$ and various concentrations of rhein $(0,0.1,1,10 \mu \mathrm{M})$ for $24 \mathrm{~h}$. Rhein markedly induced apoptosis in TNF- $\alpha$-treated HASMCs at a concentration of $10 \mu \mathrm{M}(0 \mu \mathrm{M} 1 \%, 0.1 \mu \mathrm{M}$ 21\%, $1 \mu \mathrm{M} \mathrm{32 \% ,} 10 \mu \mathrm{M} 71 \%$; fig. 2a). To further confirm the apoptosis induced by rhein in TNF- $\alpha$-treated HASMCs, we investigated the cleavage of PARP, which responds to DNA strand breaks and is used as another 
Fig. 2. Rhein induces apoptosis in TNF- $\alpha$ treated HASMCs. HASMCs were incubated with the indicated concentrations of rhein for $24 \mathrm{~h}$. a Rhein dose-dependently induced apoptotic cells. Apoptosis was measured by staining with FITC-labeled annexin V and PI, followed by flow cytometric analysis and determination of the percentage of apoptotic cells. Normal = Annexin V negative and PI negative; early apoptosis = annexin $\mathrm{V}$ positive and PI negative; late apoptosis/necrosis = annexin V positive and PI positive; others = annexin $\mathrm{V}$ negative and PI positive. $\mathbf{b}$ Rhein induces PARP cleavage. HASMCs were incubated with the indicated concentrations of rhein for $24 \mathrm{~h}$. Whole-cell lysate was obtained and used for Western blot analysis with anti-cleaved PARP $m A b$, as described in Materials and Methods. The membrane was stripped and reprobed with anti- $\beta$-actin $\mathrm{mAb}$ to confirm equal loading. Data shown are representative of at least 3 independent experiments. Data represent the means \pm SEM. ${ }^{* * *} \mathrm{p}<0.001$ vs. TNF- $\alpha$ alone.
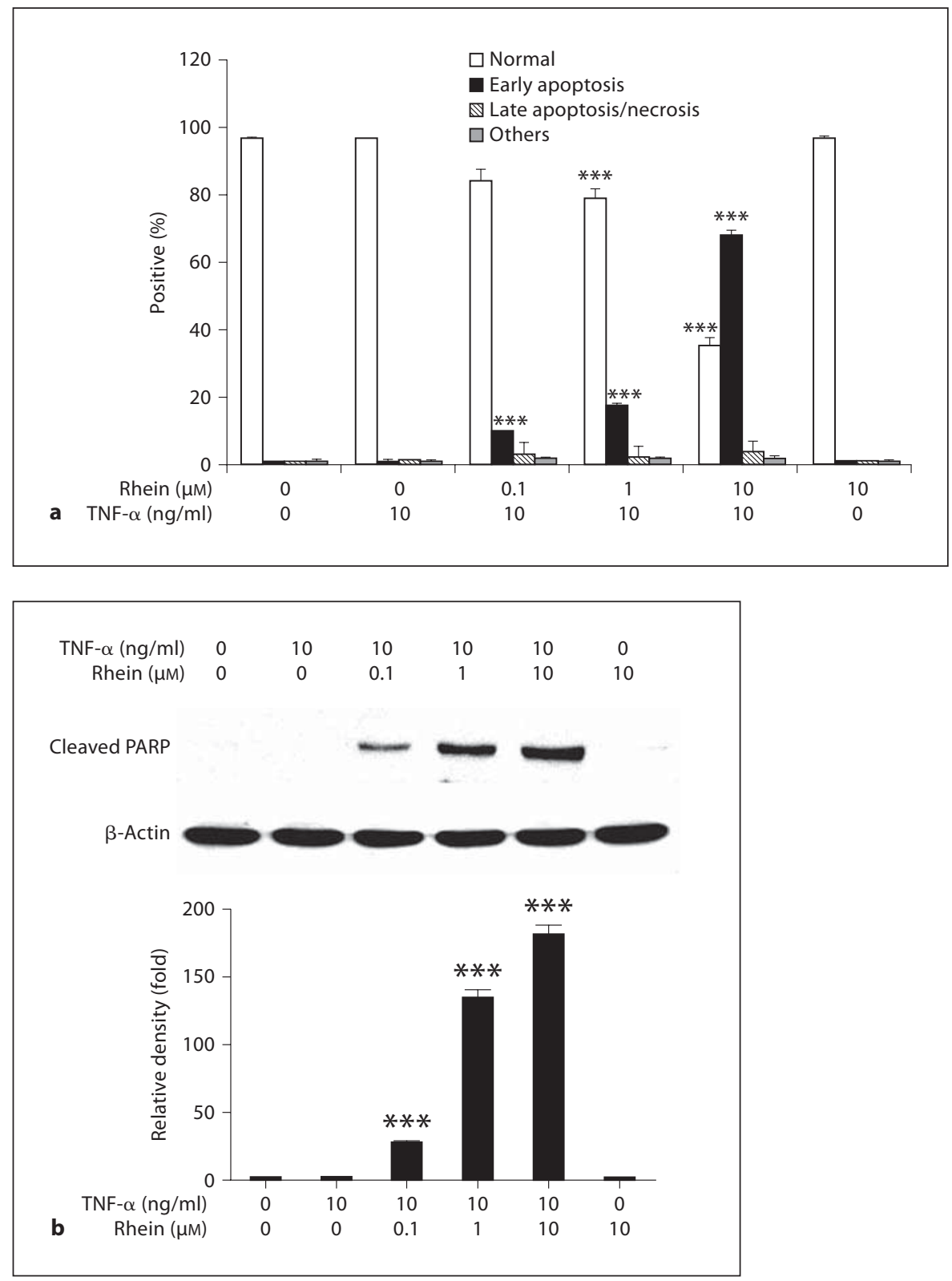

hallmark of apoptosis. As shown in figure 2b, the cleavage of PARP was detected after $24 \mathrm{~h}$ of exposure to $0.1 \mu \mathrm{M}$ of rhein. The most prominent PARP activity of rhein in TNF- $\alpha$-treated HASMCs was attained at a concentration of $10 \mu \mathrm{M}$ (relative band density with $10 \mu \mathrm{M}$ rhein was 190 fold that of the control or TNF- $\alpha$ alone group), while treatment with rhein alone $(10 \mu \mathrm{M})$ had no effect on the PARP cleavage of HASMCs (fig. 2b).

It has been reported that caspases 3,8 and 9 play pivotal roles in the terminal phase of apoptosis [24]; therefore, the rhein-induced activation of these caspases was investigated. Treatment with rhein for $24 \mathrm{~h}$ induced the cleavage and activation of caspases 3,8 and 9 in a dosedependent manner (fig. 3). The appearance of cleavage forms and the activities of the 3 caspases were observed after treatment with $0.1 \mu \mathrm{M}$ of rhein and the maximum caspase activation was observed in response to treatment with $10 \mu \mathrm{M}$ rhein (fig. 3). The relative band density is shown in figure $3 \mathrm{~b}$. Taken together, these data suggest that a caspase-dependent pathway is involved in rheininduced apoptosis. 
Fig. 3. Rhein induces activation of TNF- $\alpha$-treated HASMCs by caspases 3, 8 and 9. HASMCs were treated with rhein $(0,0.1,1,10$ $\mu \mathrm{M})$ for $24 \mathrm{~h}$. Whole cell lysates were then obtained and used for Western blot analysis with various specific antibodies, as described in Materials and Methods (a). b Relative band density (fold of treatment with TNF- $\alpha$ alone). The membrane was stripped and reprobed with anti- $\beta$-actin $\mathrm{mAb}$ to confirm equal loading. ${ }^{*} \mathrm{p}<0.05 ;{ }^{* *} \mathrm{p}<0.01 ;{ }^{* * *} \mathrm{p}<0.001$.
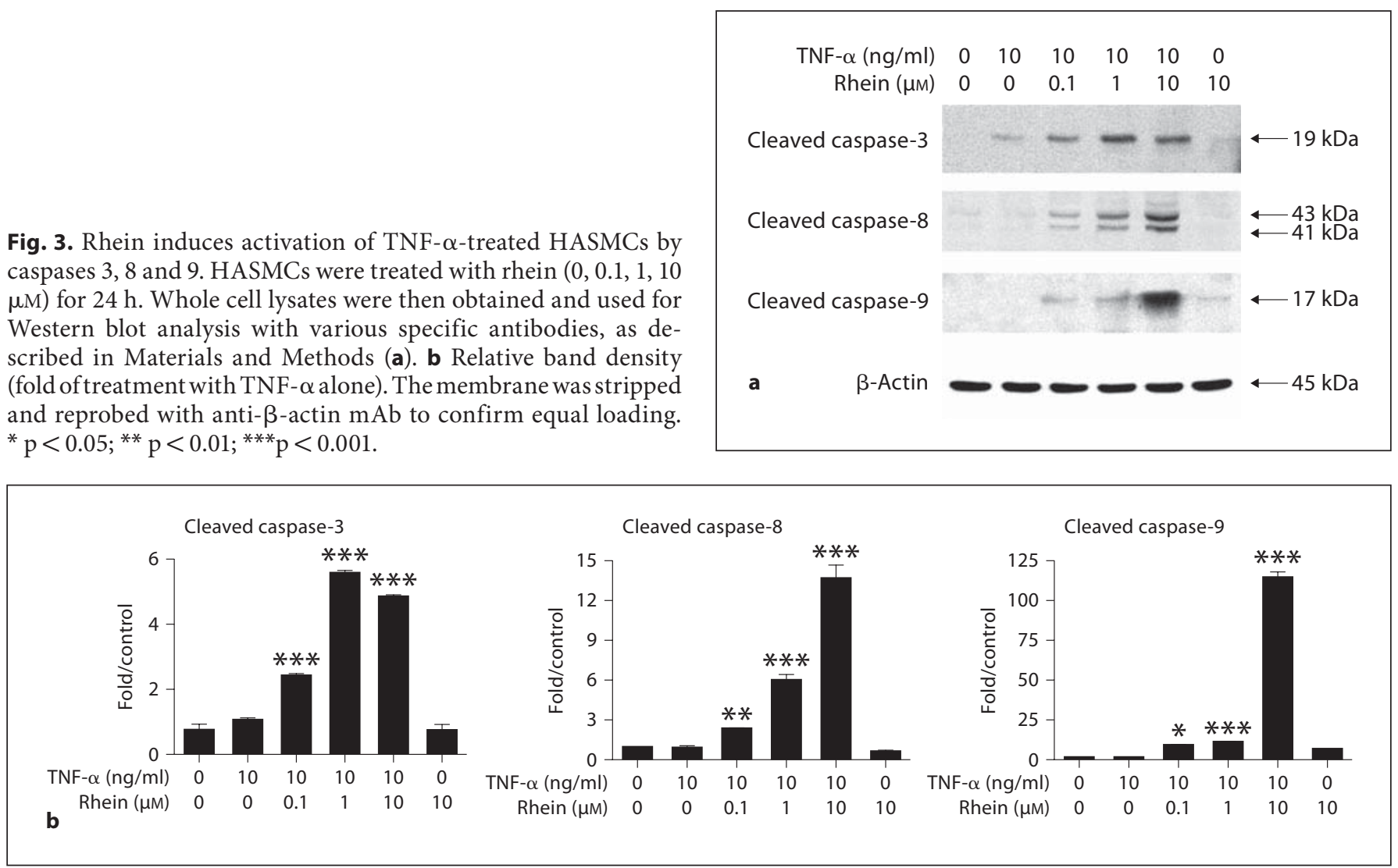

Furthermore, using inhibitors of caspases 3, 8 and 9, we confirmed that rhein-induced apoptosis is involved in the caspase pathway in TNF- $\alpha$-treated HASMCs. HASMCs were preincubated with a caspase-3 inhibitor, Ac-DEVD-CHO, a caspase-8 inhibitor, Z-IETD-FMK, or a caspase-9 inhibitor, Z-LEHD-FMK, prior to stimulation with rhein and TNF- $\alpha$, after which the presence of apoptotic cells was determined. Inhibitors of caspases 3, 8 and 9 efficiently blocked rhein-induced apoptosis in TNF- $\alpha$-treated HASMCs (percent of apoptotic cells: $10 \mu \mathrm{M}$ rhein alone $71 \%$, with $10 \mu \mathrm{M}$ Ac-DEVD-CHO 28\%, with $10 \mu \mathrm{M}$ Z-IETD-FMK 17\%, with $10 \mu \mathrm{M} \mathrm{Z}$ LEHD-FMK 23\%). The caspase-3 inhibitor, Ac-DEVD$\mathrm{CHO}$, inhibited rhein-induced apoptosis by up to $61 \%$ in TNF- $\alpha$-treated HASMCs. The caspase- 8 inhibitor, ZIETD-FMK, and the caspase-9 inhibitor, Z-LEHDFMK, also inhibited rhein-induced apoptosis by up to $77 \%$ and $66 \%$, respectively, in TNF- $\alpha$-treated HASMCs. Taken together, these findings indicate that rhein-induced cell death occurred via caspase-dependent apoptosis (fig. 4).
Rhein Induces Apoptosis via a Mitochondrial Pathway Mitochondria play a very important role in apoptosis [28]; therefore, we examined the effect of rhein on the $\Delta \psi_{\mathrm{m}}$ of TNF- $\alpha$-treated HASMCs by using a dye sensitive to potentials, $\mathrm{DiOC}_{6}(3)$. A remarkable loss of $\Delta \psi_{\mathrm{m}}$ was observed at $24 \mathrm{~h}$ in response to treatment with $10 \mu \mathrm{M}$ rhein, while treatment rhein alone $(10 \mu \mathrm{M})$ had no effect on the $\Delta \psi_{\mathrm{m}}$ of HASMCs (fig. 5a). Additionally, it has been shown that translocation of cytochrome $c$ from the mitochondria is essential to apoptotic signaling, because it induces apoptosis via the activation of caspase [29]. As shown in figure $5 \mathrm{~b}$, a dose-dependent accumulation of cytochrome $c$ in the cytosol was detected in rhein/TNF$\alpha$-treated cells, while an efflux was simultaneously observed in the mitochondria. To inhibit MMP disruption, BA $(50 \mu \mathrm{M})$ was added to HASMCs for $2 \mathrm{~h}$ prior to rhein and/or TNF- $\alpha$ treatment. After $24 \mathrm{~h}$, the cells were analyzed by immunoblotting using an anti-cytochrome $c$ $\mathrm{mAb}$. BA efficiently blocked the rhein-induced release of cytochrome $c$ in TNF- $\alpha$-treated HASMCs (relative band density: with $10 \mu \mathrm{M}$ rhein $99.5 \%$, with $50 \mu \mathrm{M}$ BA $0.5 \%$; fig. 5b). In addition, BA efficiently inhibited rhein-in- 
Fig. 4. Caspases 3, 8 and 9 are essential to rhein-induced apoptosis. HASMCs were preincubated with a caspase- 3 inhibitor, Ac-DEVD-CHO $(10 \mu \mathrm{M})$, a caspase- 8 inhibitor, Z-IETD-FMK (10 $\mu \mathrm{M})$, or caspase9 inhibitor, Z-LEHD-FMK (10 $\mu \mathrm{M})$, for $1 \mathrm{~h}$, after which they were stimulated with rhein $(10 \mu \mathrm{M})$ and TNF- $\alpha(10 \mathrm{ng} / \mathrm{ml})$ for $24 \mathrm{~h}$ and then harvested. Cells $\left(3 \times 10^{5}\right)$ were stained with FITC-labeled annexin $\mathrm{V}$, followed by FACS analysis. The filled histogram shows apoptotic cells in response to treatment with $10 \mu \mathrm{M}$ rhein in TNF- $\alpha$-treated HASMCs; the open histogram indicates the presence of the indicated caspase inhibitor, Ac-DEVD-CHO (10 $\mu \mathrm{M})$, Z-IETD-FMK (10 $\mu \mathrm{M})$, or Z-LEHDFMK $(10 \mu \mathrm{M})$ (upper panel). The lower panel shows data representing the percentage of apoptotic cells. Data shown are representative of at least 3 independent experiments and represent the means \pm SEM. ${ }^{* * *} \mathrm{p}<0.001$ vs. TNF- $\alpha$ alone.

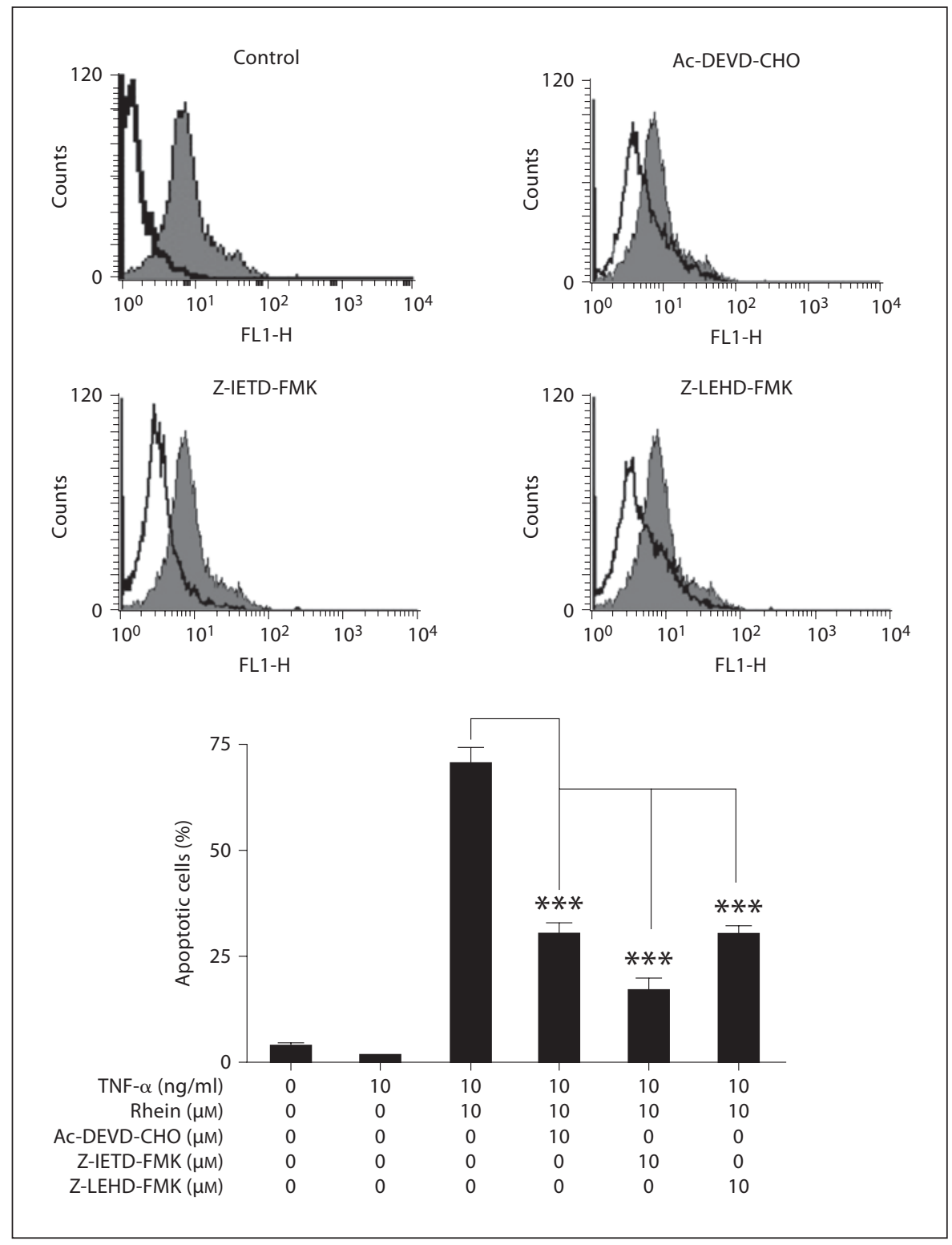

duced apoptotic cells by up to $99.5 \%$ in TNF- $\alpha$-treated HASMCs, while treatment with BA alone $(50 \mu \mathrm{M})$ had no effect on the apoptosis of HASMCs (fig. 5c). The results suggest that rhein causes an efflux of cytochrome $c$ from mitochondria via a loss of $\Delta \psi_{\mathrm{m}}$ and induces apoptosis via a mitochondrial pathway.

Mitochondrial membrane permeability is regulated by the equilibrium between pro-apoptotic and antiapoptotic members of the Bcl-2 family. Mitochondrial apoptotic pathways can be negatively regulated by the over-expression of anti-apoptotic proteins such as $\mathrm{Bcl}-2$ and Bcl-xL $[18,30,31]$. Conversely, translocation of the pro-apoptotic protein, Bax, to the mitochondrial membrane induces the release of cytochrome $c[15-17,32]$. We determined that rhein may elicit MMP disruption by regulating the expression of Bcl-2 family members. As shown in figure $6 \mathrm{a}$, the pro-apoptotic protein, Bax, in TNF- $\alpha$-treated HASMCs increased as the concentration of rhein increased (relative band density with $10 \mu \mathrm{M}$ rhein and TNF- $\alpha$ was 3.6-fold that of control groups or the group treated with TNF- $\alpha$ alone). By comparison, the anti-apoptotic proteins, $\mathrm{Bcl}-2$ and $\mathrm{Bcl}-\mathrm{xL}$, decreased as the concentration of rhein increased (relative band density with $10 \mu \mathrm{M}$ rhein and TNF- $\alpha$ showed $80-90 \%$ 
Fig. 5. Rhein-induced apoptosis involves the mitochondrial pathway. a HASMCs were treated with $0.1,1$, or $10 \mu \mathrm{M}$ rhein in the presence or absence of TNF- $\alpha$ (10ng/ $\mathrm{ml})$ for $24 \mathrm{~h}$, and then harvested. Cells (3 $\times 10^{5}$ ) were stained with $\mathrm{DiOC}_{6}(3)$ dye, followed by FACS analysis. $\mathbf{b}$ TNF- $\alpha$-treated HASMCs were incubated with $0.1,1$, and $10 \mu \mathrm{M}$ rhein in the presence or absence of BA $(50 \mu \mathrm{M})$ for $24 \mathrm{~h}$, after which they were harvested. The mitochondrial and cytosolic fractions were then separated, after which $30 \mu \mathrm{g}$ of each sample was analyzed for the expression of cytochrome $c$. The membrane was stripped and reprobed with anti- $\beta$-actin $\mathrm{mAb}$ to confirm equal loading. c TNF- $\alpha$-treated HASMCs were incubated with rhein $(10 \mu \mathrm{M})$ in the presence or absence of BA $(50 \mu \mathrm{M})$ for $24 \mathrm{~h}$, and then harvested. Cells $\left(3 \times 10^{5}\right)$ were stained with FITC-labeled annexin V and PI, followed by FACS analysis. Data show the percentage of apoptotic cells. Normal = Annexin V negative and PI negative; early apoptosis = annexin $\mathrm{V}$ positive and PI negative; late apoptosis/necrosis = annexin V positive and PI positive; others = annexin $\mathrm{V}$ negative and PI positive. Data shown are representative of at least 3 independent experiments and represent the means \pm SEM. ${ }^{*} \mathrm{p}<0.05 ;{ }^{* *} \mathrm{p}<0.01 ;{ }^{* * *} \mathrm{p}<0.001$ vs. TNF- $\alpha$ alone.
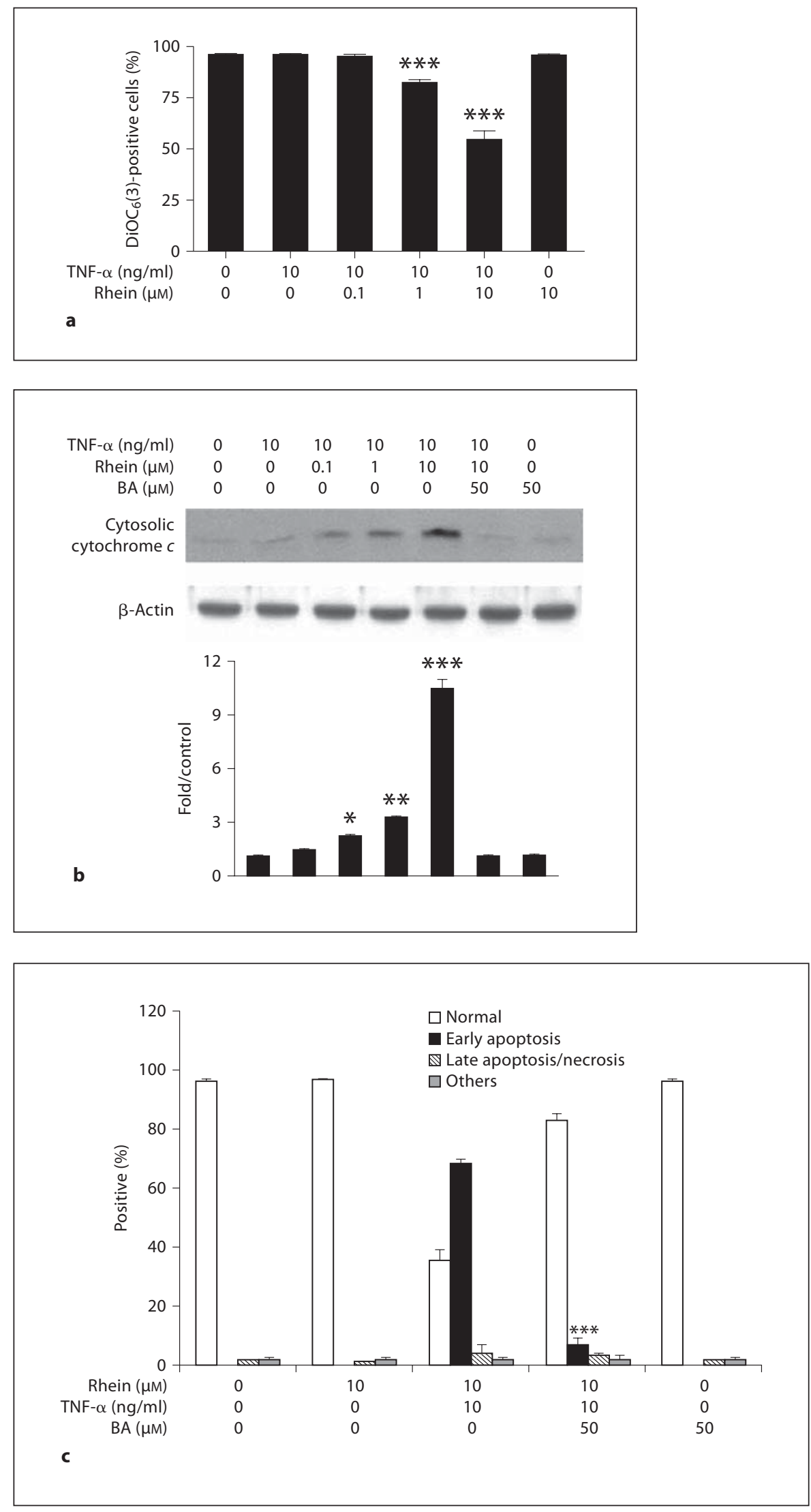


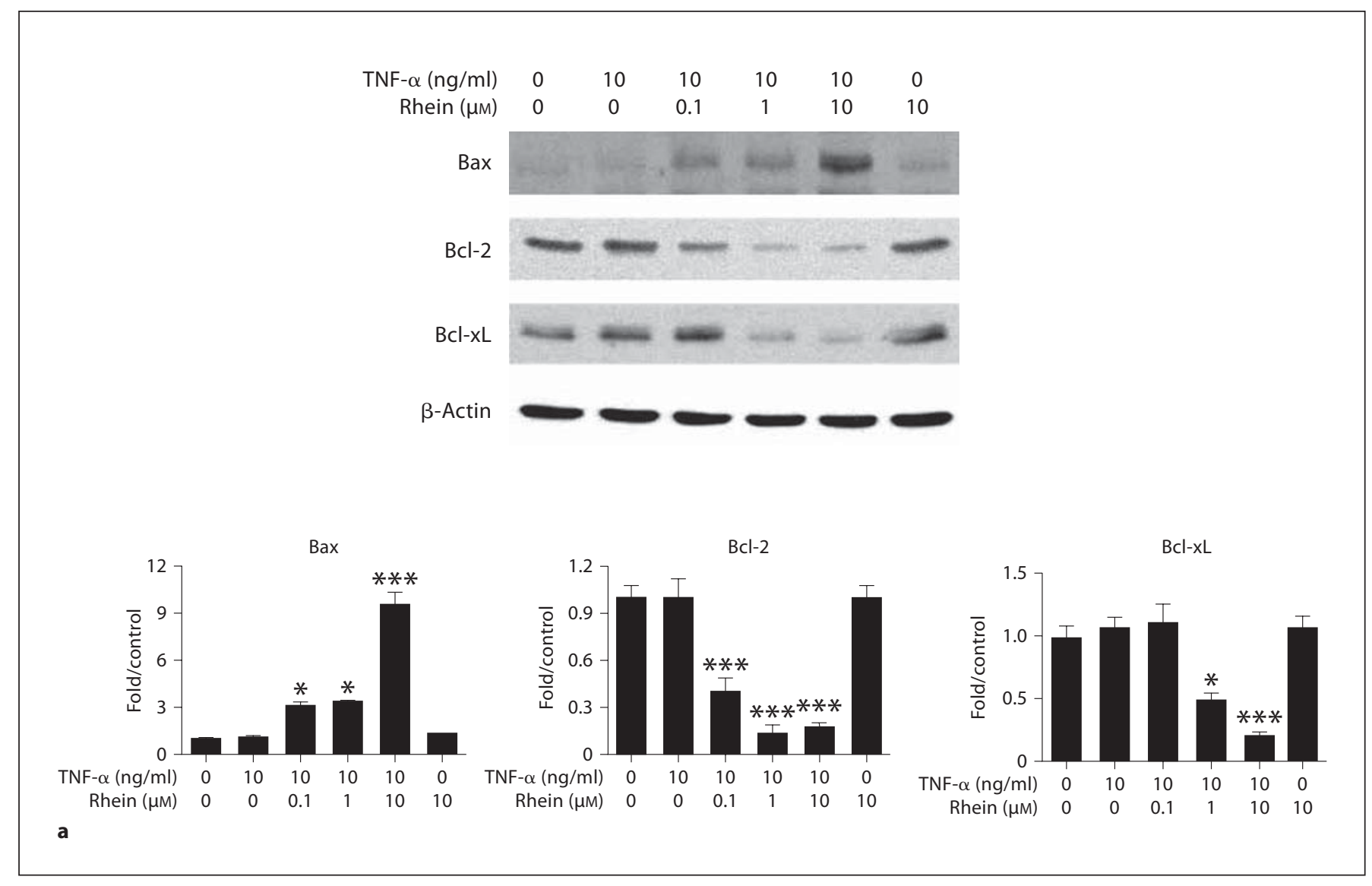

Fig. 6. Rhein regulates the expression of Bcl-2 family proteins. TNF- $\alpha$-treated HASMCs were incubated with the indicated dosages of rhein for $24 \mathrm{~h}$ at $37^{\circ} \mathrm{C}$. The supernatants of the cell lysates were then analyzed by Western blotting for the expression of Bax, $\mathrm{Bcl}-2$, and $\mathrm{Bcl}-\mathrm{xL}$. The membrane was stripped and reprobed with anti- $\beta$-actin $\mathrm{mAb}$ to confirm equal loading. a Dose-dependent responses of $\mathrm{Bax}, \mathrm{Bcl}-2$, and $\mathrm{Bcl}-\mathrm{xL}$. The relative band density is also shown in the lower panel. $\mathbf{b}$ Rhein induces Bak expression in a dose-dependent manner via MMP disruption. HASMCs were pretreated with the MMP disruption inhibitor (BA, $50 \mu \mathrm{M})$ for $2 \mathrm{~h}$, after which they were exposed to $10 \mu \mathrm{M}$ rhein and $10 \mathrm{ng} / \mathrm{ml}$ TNF- $\alpha$ for $24 \mathrm{~h}$ at $37^{\circ} \mathrm{C}$. Cells underwent intracellular staining with anti-Bak mAb, as described in Materials and Methods. Data shown are representative of at least 3 independent experiments and represent the means \pm SEM. ${ }^{*} \mathrm{p}<0.05 ;{ }^{* *} \mathrm{p}<0.001$ vs. TNF- $\alpha$ alone.

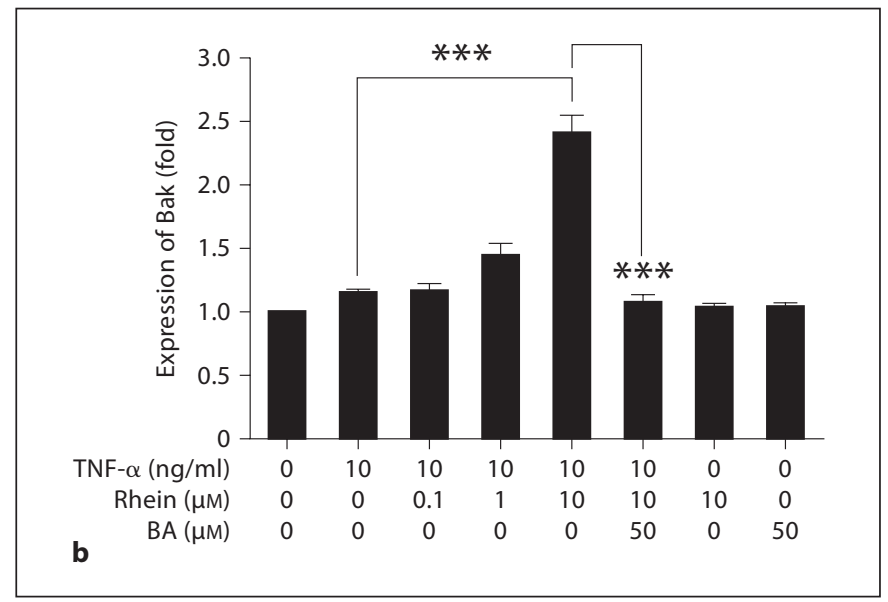

inhibition compared to the group treated with TNF- $\alpha$ alone). In addition, the pro-apoptotic protein, Bak, increased as the concentration of rhein increased in TNF$\alpha$-treated HASMCs (relative band density with $10 \mu \mathrm{M}$ rhein and TNF- $\alpha$ was 2.5 -fold that of control groups or the group treated with TNF- $\alpha$ alone). Furthermore, the MMP disruption inhibitor, BA, efficiently blocked rhe-

in-induced Bak expression by up to $90 \%$ in TNF- $\alpha$-activated HASMCs, as shown in figure 6b. Taken together, these findings indicate that rhein induces Bak expression via MMP disruption. Furthermore, these data suggest that rhein-induced apoptosis might be regulated by mitochondrial disorganization. Therefore, rhein induces apoptosis via a mitochondrial pathway. 


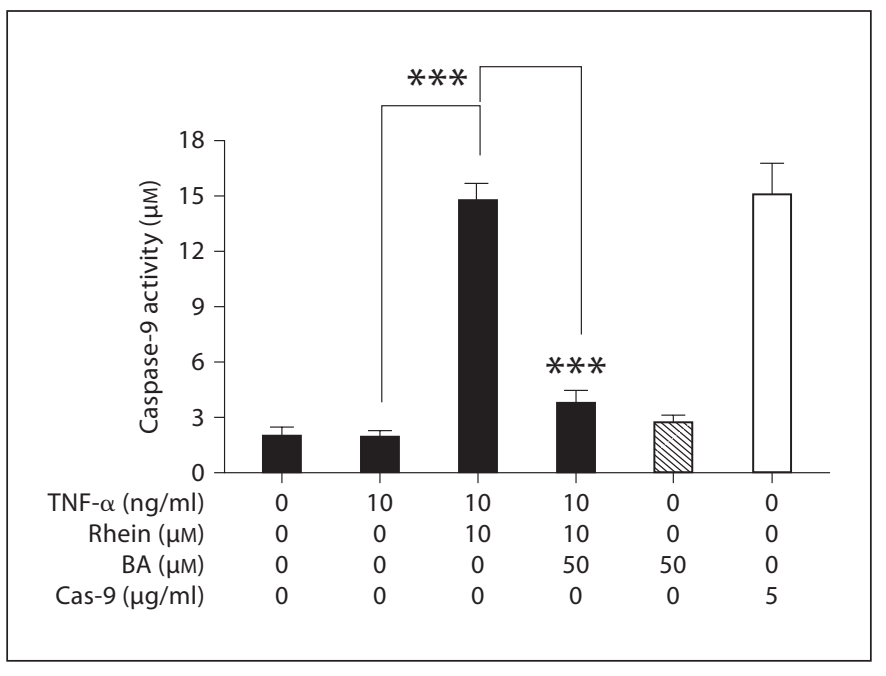

Fig. 7. Effect of BA in rhein-induced caspase-9 activation. HASMCs were pretreated with MMP disruption inhibitor (BA) for $2 \mathrm{~h}$, exposed to $10 \mu \mathrm{M}$ rhein and $10 \mathrm{ng} / \mathrm{ml} \mathrm{TNF}-\alpha$ for $24 \mathrm{~h}$ at $37^{\circ} \mathrm{C}$ and then lysed. The caspase- 9 activity was measured as described in Materials and Methods. Data shown are representative of at least 3 independent experiments and represent the means \pm SEM. ${ }^{* *}$ p $<0.001$ vs. TNF- $\alpha$ alone. Cas $-9=$ Caspase -9 as a positive control.

\section{Mitochondrial Membrane Depolarization Inhibitor}

Efficiently Blocked Rhein-Induced Caspase-9 Activity

The results of this study demonstrated that rhein-induced apoptosis occurs via caspases 3, 8 and 9 activation (fig. 3 and 4). Therefore, to determine the hierarchy of caspase and mitochondria, caspase- 9 activity was measured in the presence or absence of the MMP disruption inhibitor, BA. BA efficiently blocked rhein-induced caspase- 9 activation in TNF- $\alpha$-activated HASMCs, as shown in figure 7, which indicates that rhein-induced caspase activation occurs downstream of the mitochondrial pathway. We also used caspase- 9 as a positive control. The level of rhein-mediated caspase- 9 activity in TNF- $\alpha$ treated HASMCs was comparable with that of caspase-9mediated induction.

\section{Discussion}

The abnormal growth of VSMCs plays an important role in the development of vascular diseases such as atherosclerosis and restenosis following angioplasty $[1,2]$. In addition, abnormal growth of VSMCs also induces inflammation in blood vessels and/or arteries [3]. Inflammatory cytokines such as TNF- $\alpha$ are secreted by VSMCs in the neointima after a balloon injury, as well as by macrophages in atherosclerotic lesions [33]. In addition, inflammatory cytokines also play an important role in the induction of inflammation, migration and proliferation in HASMCs [3-8].

Previous reports have shown that rhein induces apoptosis in promyelocytic leukemia HL-60 cells [24], and it is well known TNF- $\alpha$-induced HASMC proliferation plays a critical role in development of vascular diseases including atherosclerosis [2, 5-9]. However, the effect of rhein on TNF- $\alpha$-induced HASMC proliferation is not well understood. Moreover, most investigations have shown that some materials, such as quercetin [5], resveratrol [6], gensenoside [7], ochnaflavone [8], and magnolol [9], inhibit TNF- $\alpha$-induced HASMC proliferation by regulating cell cycle-related proteins and by suppressing the activities of extracellular signal-regulated kinases 1 and 2. However, it is less well known that the inhibition of TNF- $\alpha$-induced HASMC proliferation occurs via caspase and a mitochondrial-dependent apoptotic pathway.

Rhein inhibits TNF- $\alpha$-induced HASMC proliferation (fig. 1). It is well known that TNF- $\alpha$ functions both as a survival signal including proliferation (via DNA synthesis) and as a death signal [34]. Therefore, we attempted to confirm the effects of rhein on TNF- $\alpha$-induced proliferation of HASMCs, not TNF- $\alpha$-induced cell death. Cell proliferation was measured by a BrdU-(5'Bromo-2-deoxyuridine) ELISA assay (cell proliferation ELISA BrdU), which produced results very similar to those obtained when the cell viability was assayed (fig. 1b). Moreover, other studies conducted to evaluate TNF- $\alpha$-induced HASMC proliferation measured thymidine incorporation in conjunction with tritium and found that TNF- $\alpha$ induces an increase in DNA synthesis, as well as the proliferation of HASMCs $[5,6,8,9]$.

Rhein induces apoptotic cells (fig. 2a), PARP cleavage (fig. 2b), and caspase activation (fig. 3; also shown using caspase inhibitors in fig. 4) in TNF- $\alpha$-treated HASMCs. Rhein also induces a release of cytochrome $c$ from mitochondria through a loss of $\Delta \psi_{\mathrm{m}}$ (fig. 5a, b), a decreased Bcl-2 and Bcl-xL level, and an increased Bax and Bak protein level (fig. 6). These findings indicate that the activation of caspases and a mitochondrial pathway is required for rhein-induced apoptosis in TNF- $\alpha$-treated HASMCs. This study also demonstrated that caspases 3,8 and 9 and mitochondria contribute directly to rhein-mediated apoptosis (fig. 4, 5c). The caspase-3 inhibitor, Ac-DEVD$\mathrm{CHO}$, inhibited rhein-induced apoptosis by up to $61 \%$ in TNF- $\alpha$-treated HASMCs. Additionally, the caspase- 8 inhibitor, Z-IETD-FMK, and the caspase-9 inhibitor, Z- 
LEHD-FMK, also inhibited rhein-induced apoptosis by up to 77 and $66 \%$, respectively, in TNF- $\alpha$-treated HASMCs (fig. 4). Furthermore, BA (an inhibitor of MMP disruption) efficiently inhibited rhein-induced apoptotic cells by up to $74 \%$ in TNF- $\alpha$-treated HASMCs (fig. 5 c). It should be noted that inhibitors of caspases 3, 8 and 9 did not block rhein-induced $\Delta \psi_{\mathrm{m}}$ (data not shown). In addition, the inhibitor of mitochondrial membrane depolarization efficiently blocked rhein-induced caspase- 9 activity, as shown in figure 7. This finding indicates that caspase signals exist downstream of the mitochondrial pathway. Taken together, these results indicate that rhein-induced cell death occurred via mitochondria-dependent apoptosis.

It is well known that TNF- $\alpha$ acts as a double-edged sword by functioning as a survival signal that induces proliferation (via DNA synthesis), but also as a death signal [34]. Moreover, rhein has been shown to induce death during TNF- $\alpha$-induced VSMC proliferation via the induction of apoptosis. It is possible that TNF- $\alpha$-induced VSMC proliferation occurs via the recruitment of TNFreceptor-associated factors 1 and 2 in downstream of the TNF receptors; however, treatment of TNF- $\alpha$-induced HASMC with rhein resulted in the proliferation signal changing to an apoptosis signal and causing the recruitment of Fas-associated death domain protein and caspase 8 [35]. We will evaluate these effects in a future study using several inhibitors to better understand how they occur. However, it is obvious that rhein inhibits TNF- $\alpha$-induced human aortic smooth-muscle cell proliferation via caspase- and mitochondrial-dependant apoptosis. Moreover, rhein prevents overgrowth of VSMC and the development of atherosclerosis. Taken together, these findings indicate that rhein can be used to prevent atherosclerosis via the induction of apoptosis in VSMC.

The results of this study suggest that rhein-treated HASMCs are killed via apoptosis in atherosclerotic lesions and inflammation (TNF $\alpha$-affected HASMCs), which promotes PARP cleavage and caspase activation, subsequently releasing cytochrome $c$ from the mitochondria as a result of a loss of $\Delta \psi_{\mathrm{m}}$ (mitochondrial disorganization). This in turn decreases the level of the Bcl-2 and $\mathrm{Bcl}-\mathrm{xL}$ survival proteins, and increases the level of Bax and Bak apoptotic proteins. It is interesting that treatment with rhein alone $(10 \mu \mathrm{M})$ had no effect on proliferation (fig. 1b), apoptosis (fig. 2a), PARP cleavage (fig. 2b), caspase activation (fig. 3), loss of $\Delta \psi_{\mathrm{m}}$ (fig. 5a), cytochrome $c$ release (fig. 5b), or Bax and Bak expression (fig. 6a, b) in HASMCs. This indicates that rhein only induces cell death in inflammatory sites.
It is well known that the consequences of VSMC apoptosis depend on the stage and location of the plaque SMC at the time of death [36]. Furthermore, the consequences of VSMC apoptosis can also be detrimental to the overall stability of the plaque, thereby causing thrombosis and rupture [37]. However, the exact role that apoptosis plays in the pathology and physiology of coronary diseases such as atherosclerosis is currently unknown. In addition, the effect that rhein-mediated VSMC apoptosis has on thrombosis and plaque rupture is not yet known and will be evaluated in a future study using animal models. However, it is obvious that rhein inhibits TNF- $\alpha$-induced HASMC proliferation via caspase- and mitochondrialdependant apoptosis. Moreover, rhein prevents the overgrowth of VSMC and the development of atherosclerosis. Therefore, rhein can be used to prevent atherosclerosis via the induction of apoptosis in VSMC.

Rhein, a constituent enriched in the rhizome of rhubarb (R.palmatum L. or R. tanguticum Maxim, daehwang in Korean), is a traditional Chinese herb that is used as a laxative and stomachic drug [19]. Although it is well known that rhein has anti-cancer activity in various cells, including human glioma [20], tumor cells in the rat liver [21], Ehrlich ascites tumor cells [22], human colonic adenocarcinoma [23], the mouse epidermal cell line JB6 [19], human promyelocytic leukemia HL-60 cells [24], and human cervical cancer Ca Ski cells [25], little is known about the anti-atherogenic effects of rhein or its signal pathway (and mechanism) in HASMCs. However, other anthraquinone components of rhubarb, such as aloe-emodin and emodin, also reportedly exert anti-proliferation effects in VSMCs following arterial injury $[38,39]$.

In conclusion, rhein inhibits TNF- $\alpha$-induced HASMC proliferation via a mitochondria-dependent apoptotic pathway, which indicates that rhein has the potential for use as an anti-atherosclerosis agent. In addition, rhein may be particularly useful for the prevention of restenosis following percutaneous transluminal coronary angioplasty. To our knowledge, this is the first report to indicate that the inhibition of TNF- $\alpha$-induced HASMC proliferation is directly involved in mitochondrial-dependent apoptosis.

\section{Acknowledgments}

This work was supported by the Dongguk University Research Fund and the MRC program of MOST/KOSEF (grant No. R132005-013-01000-0). 


\section{References}

1 Ross R: Cell biology of atherosclerosis. Annu Rev Physiol 1995;57:791-804.

-2 Owens GK, Kumar MS, Wamhoff BR: Molecular regulation of vascular smooth muscle cell differentiation in development and disease. Physiol Rev 2004;84:767-801.

-3 Jovinge S, Hultgardh-Nilsson A, Regnstrom J, Nilsson J: TNF- $\alpha$ activates smooth muscle cell migration in culture and is expressed in the balloon-injured rat aorta. Arterioscler Thromb Vasc Biol 1997;17:490-497.

-4 Tanaka H, Sukhova G, Schwartz D, Libby P: Proliferating arterial smooth muscle cells after balloon injury express TNF-alpha but not interleukin-1 or basic fibroblast growth factor. Arterioscler Thromb Vasc Biol 1996;16: $12-18$.

5 Moon SK, Cho GO, Jung SY, Gal SW, Kwon TK, Lee YC, Madamanchi NR, Kim CH: Quercetin exerts multiple inhibitory effects on vascular smooth muscle cells: role of ERK1/2, cell-cycle regulation, and matrix metalloproteinase-9. Biochem Biophys Res Commun 2003;301:1069-1078.

6 Lee B, Moon SK: Resveratrol inhibits TNFalpha-induced proliferation and matrix metalloproteinase expression in human vascular smooth muscle cells. J Nutr 2005; 135 : 2767-2773.

7 Zhang HS, Wang SQ: Ginsenoside Rg1 inhibits tumor necrosis factor-alpha (TNF-alpha)-induced human arterial smooth muscle cells (HASMCs) proliferation. J Cell Biochem 2006;98:1471-1481.

-8 Suh SJ, Jin UH, Kim SH, Chang HW, Son JK, Lee SH, Son KH, Kim CH: Ochnaflavone inhibits TNF-alpha-induced human VSMC proliferation via regulation of cell cycle, ERK1/2, and MMP-9. J Cell Biochem 2006; 99:1298-1307.

9 Kim HM, Bae SJ, Kim DW, Kim BK, Lee SB, Lee US, Kim CH, Moon SK: Inhibitory role of magnolol on proliferative capacity and matrix metalloproteinase- 9 expression in TNF-alpha-induced vascular smooth muscle cells. Int Immunopharmacol 2007; 1083-1091.

10 Thornberry NA: Caspases: key mediators of apoptosis. Chem Biol 1998;5:R97-R103.

-11 Budihardjo I, Oliver H, Lutter M, Luo X, Wang X: Biochemical pathways of caspase activation during apoptosis. Annu Rev Cell Dev Biol 1999;15:269-290.

-12 Slee EA, Harte MT, Kluck RM, Wolf BB, Casiano CA, Newmeyer DD, Wang HG, Reed JC, Nicholson DW, Alnemri ES, Green DR, Martin SJ: Ordering the cytochrome $c$-initiated caspase cascade: hierarchical activation of caspases-2, -3, -6, -7, -8, and - 10 in a caspase-9-dependent manner. J Cell Biol 1999; 144:281-292.

13 Wyllie AH: Glucocorticoid-induced thymocyte apoptosis is associated with endogenous endonuclease activation. Nature 1980;284: 555-556.
14 Cory S, Adams JM: The Bcl2 family: regulators of the cellular life-or-death switch. Nat Rev Cancer 2002;2:647-656.

15 Jürgensmeier JM, Xie Z, Deveraux Q, Ellerby L, Bredesen D, Reed JC: Bax directly induces release of cytochrome $\mathrm{c}$ from isolated mitochondria. Proc Natl Acad Sci 1998;95:49975002.

16 Park MT, Kang JA, Choi JA, Kang CM, Kim TH, Bae S, Kang S, Kim S, Choi WI, Cho CK, Chung HY, Lee YS, Lee SJ: Phytosphingosine induces apoptotic cell death via caspase 8 activation and Bax translocation in human cancer cells. Clin Cancer Res 2003;9:878885.

-17 Antonsson B, Montessuit S, Sanchez B, Martinou JC: Bax is present as a high molecular weight oligomer/complex in the mitochondrial membrane of apoptotic cells. J Biol Chem 2001;276:11615-11623.

18 Finucane DM, Bossy-Wetzel E, Waterhouse NJ, Cotter TG, Green DR: Bax-induced caspase activation and apoptosis via cytochrome $c$ release from mitochondria is inhibitable by Bcl-xL. J Biol Chem 1999;274: 2225-2233.

19 Lin S, Li JJ, Fujii M, Hou DX: Rhein inhibits TPA-induced activator protein-1 activation and cell transformation by blocking the JNK-dependent pathway. Int J Oncol 2003; 22:829-833.

20 Delpino A, Paggi MG, Gentile PF, Castiglione S, Bruno T, Benass M, Floridi A: Protein synthetic activity and adenylate energy charge in Rhein-treated cultured human glioma cells. Cancer Biochem Biophys 1992;12: 241-252.

21 Miccadei S, Pulselli R, Floridi A: Effect of lonidamine and rhein on the phosphorylation potential generated by respiring rat liver mitochondria. Anticancer Res 1993; 13: 1507-1510.

22 Castiglione S, Fanciulli M, Bruno T, Evangelista M, Del Carlo C, Paggi MG, Chersi A, Floridi A: Rhein inhibits glucose uptake in Ehrlich ascites tumor cells by alteration of membrane-associated functions. Anticancer Drugs 1993;4:407-414.

23 Raimondi F, Santoro P, Maiuri L, Londei M, Annunziata S, Ciccimarra F, Rubino A: Reactive nitrogen species modulate the effects of rhein, an active component of senna laxatives, on human epithelium in vitro. Pediatr Gastroenterol Nutr 2002;34:529-534.

24 Lin S, Fujii M, Hou DX: Rhein induces apoptosis in HL-60 cells via reactive oxygen species-independent mitochondrial death pathway. Arch Biochem Biophys 2003;418: 99-107.

25 Ip SW, Weng YS, Lin SY, Mei-Dueyang, Tang NY, Su CC, Chung JG: The role of $\mathrm{Ca}^{2+}$ on rhein-induced apoptosis in human cervical cancer Ca Ski cells. Anticancer Res 2007;27: 379-389.
26 Hur YG, Yun Y, Won J: Rosmarinic acid induces p56 lck-dependent apoptosis in Jurkat and peripheral $\mathrm{T}$ cells via mitochondrial pathway independent from Fas/Fas ligand interaction. J Immunol 2004;172:79-87.

27 Wang H, Wang Z, Chen J, Wu J: Apoptosis induced by NO via phosphorylation of $\mathrm{p} 38$ MAPK that stimulates NF-kappaB, p53 and caspase-3 activation in rabbit articular chondrocytes. Cell Biol Int 2007;31:1027-1035.

28 Petit PX, Zamzami N, Vayssiere JL, Mignotte B, Kroemer G, Castedo M: Implication of mitochondria in apoptosis. Mol Cell Biochem 1997;174:185-188.

-29 Singh SV, Zeng Y, Xiao D, Vogel VG, Nelson JB, Dhir R, Tripathi YB: Caspase-dependent apoptosis induction by guggulsterone, a constituent of Ayurvedic medicinal plant Commiphora mukul, in PC-3 human prostate cancer cells is mediated by Bax and Bak. Mol Cancer Ther 2005;4:1747-1754.

30 Yang J, Liu X, Bhalla K, Kim CN, Ibrado AM, Cai J, Peng TI, Jones DP, Wang X: Prevention of apoptosis by Bcl-2: release of cytochrome c from mitochondria blocked. Science 1997; 275:1129-1132.

-31 Garland JM, Rudin C: Cytochrome $c$ induces caspase-dependent apoptosis in intact hematopoietic cells and overrides apoptosis suppression mediated by bcl-2, growth factor signaling, MAP-kinase-kinase, and malignant change. Blood 1998;92:1235-1246.

32 Gustafsson AB, Gottlieb RA: Bcl-2 family members and apoptosis, taken to heart. Am J Physiol Cell Physiol 2007;292:C45-C51.

33 Tipping PG, Hancock WW: Production of tumor necrosis factor and interleukin-1 by macrophages from human atherosclerotic plaques. Am J Pathol 1993;142:1721-1728.

34 Aggarwal BB: Signalling pathways of the TNF superfamily: a double-edged sword. Nat Rev Immunol 2003;3:745-756.

35 Baud V, Karin M: Signal transduction by tumor necrosis factor and its relatives. Trends Cell Biol 2001;11:372-377.

-36 Rakesh K, Agrawal DK: Cytokines and growth factors involved in apoptosis and proliferation of vascular smooth muscle cells. Int Immunopharmacol 2005;5:14871506.

37 Bauriedel G, Hutter R, Welsch U, Bach R, Sievert H, Lüderitz B: Role of smooth muscle cell death in advanced coronary primary lesions: implications for plaque instability. Cardiovasc Res 1999;41:480-488.

38 Yin C, Xu C: Effect of aloe-emodin on proliferation of vascular smooth muscle cells after arterial injury (in Chinese). Zhongguo. Zhong. Xi Yi Jie He Za Zhi 1998;18:420422.

39 Guo D, Xu C, Chen Y: A study on the effect of emodin on smooth muscle cell proliferation (in Chinese). Zhonghua Nei Ke Za Zhi 1996;35:157-159. 